運動生理 8(1):39-46,1993.

シソポジウム

\title{
上肢接触板移動時の筋電図反応時間 についての解析
}

岩月宏泰 ${ }^{1}$ 室賀辰夫 ${ }^{21}$

Analysis of EMG Reaction Time in the Stereotyped Movements of Upper Extremities on Contact Boards.

Hi royasu IWATSUKI, RPT ${ }^{1)}$, Tatsuo MUROGA,OTR ${ }^{2}$ ).

1) Department of Physical Therapy, College of Medical Technology, Nagoya University: 1-1-20 Daikouminami Higashi-ku Nagoya 461 Japan. TEL +81 052-723-1111.

2) Department of Occupational Therapy, College of Medical Technology, Nagoya University

J. Exerc. Physiol. 8(1):39-46,1993. Submited April 18,1992. Accepted 0ct.16,1992.

ABSTRACT

This study was designed to examine the reaction time (RT) of the upper extremity agonist during shift motions among contact boards by using electromyogram, and to analyze the effects of the frequency of stimuli, disorders subjects suffered, and dominancy of the hand examined on RT. The premotor time of the elderly subjects was found to approximately $130 \mathrm{~ms}$, which was unchanged in spite of variation of the frequency from 0.2 to $1.2 \mathrm{~Hz}$. This suggests that the elderly persons may respond to different stimuli by the fixed movement pattern. To any stimuli, there was no difference in the ratio of $R T$ to the required time for finishing the motion between Spino-cerebellar degenerations (SCD) and Parkinsonism (PS) patients. It was assumed from this fact that either abnormal muscle tonus or reciprocal, synchronous disorder in muscle contraction may play an important role in inducing disability of motor "switching mechanism".

Key words: EMG-RT, shift motions of upper extremities, Spino-cerebellar Degeneration (SCD), Parkinsonism(PS).

要旨

本稿では上肢の接触板移動運動の軌跡と主動筋の筋活動から筋電図反応時間を計測し合図の 頻度、小脳障害と錐体外路䒺障害の差異および利き手の特性などについて述べた。

刺激頻度別によるRTの比較では、老年者のPMTが $0.2 \sim 1.2 \mathrm{~Hz}$ まで約 $130 \mathrm{~ms}$ と変化しなかったこと から、老年者では一定の運動パターンでしか対応できないことが推測された。全所要時間にRT の占める割合はSCD、PSとも刺激条件に関わらず両群間に差を認めなかったことから、”運動の 切り換え”の障害には筋トーヌス異常、相反性同期性障害の関与が大きいことが推測された。 今後、運動開始時の筋電図周波数分析から合図に対する予測効果を運動単位の活動様態から運 動準備状態を検索する予定である。

キーワード:筋電図反応時間、上肢移動運動、小脳障害、パーキンソニズム

1) 名古屋大学医療技術短期大学部理学療法学科：愛知県名古屋市東区大幸南1-1-20（宁461）

2) 同作業療法学科

受付日 1992 年 4 月 22 日 受理日 1992 年 10 月 16 日 


\section{I 、はじめに}

反応時間研究は種々の分野の研究者によっ てなされており、特定の刺激が与えられた時 に直ちに反応する簡単反応時間、および弁別、 判断、選択、情報処理過程の複雑反応時間に

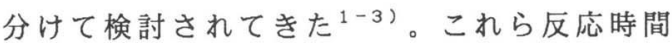
を規定する要因として、合図の質、強度、予 告信号の効果などの実験系に起因するもの、

練習、覚醒、注意程度など被験者に由来する

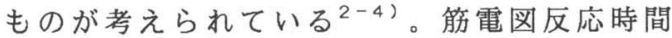
（EMG-RT）は刺激の感知一大脳皮質一主動筋 までの生体情報が反応時間として表出される ため、機械的な遅れ等が介在しない。このEM G-RTの測定方法はWeiss ${ }^{1)}$ により確立され、本 邦でも中村らを始めとして数多くの研究がさ

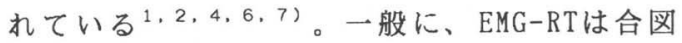
から筋活動開始までの時間 (Premotor time; PMT) と筋活動から実際の運動開始までの時間 (Motortime;MT)の変数に分けて検討されてい

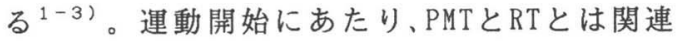
が梁いが、PMTと MT間では関連が少ないこと が明らかにされている2,11)。このEMG-RTの利 点はPMTとMTの区別で中枢、末梢過程を弁別で き、姿勢調節機構、意図的運動の関連を探求 できる点であり、久点としてEMG-RT と筋電図 記録の変数（振幅、周波数など）、運動学的 ・運動力学的変数との関連が不明が挙げられ

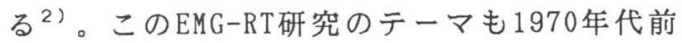
半が肢位、構えの操作を後半以降には運動準 備、運動プログラムの解析が運動軌跡との関 連と変化している2゙。我々は今までに上肢に おりる接触板移動運動時の主動筋の筋電図反 応時間と運動軌跡から運動発現について検討 してきた。

今回、その研究成果を表のごとく1）規則 刺激の頻度による比較、2）規則刺激と不規 則刺激による比較、3）パーキンソニズムと 小脳障害との比較、4) 接触板離着時の筋電 図周波数分析、5) 利き手の特性、6) 視覚
入力の有無が筋電図反応時間に及ぼす影響の 順序で紹介し今後の展望についても報告する。

表：項 目

1）規則刺激の頻度による比較

2) 規則刺激と不規則刺激による比較

3）バーキンソニズムと小脳障害との比較

4) 接触板離着時の筋電図周波数分析

5) 利き手の特性

6) 視覚入力の有無が運動発現に及活す影響

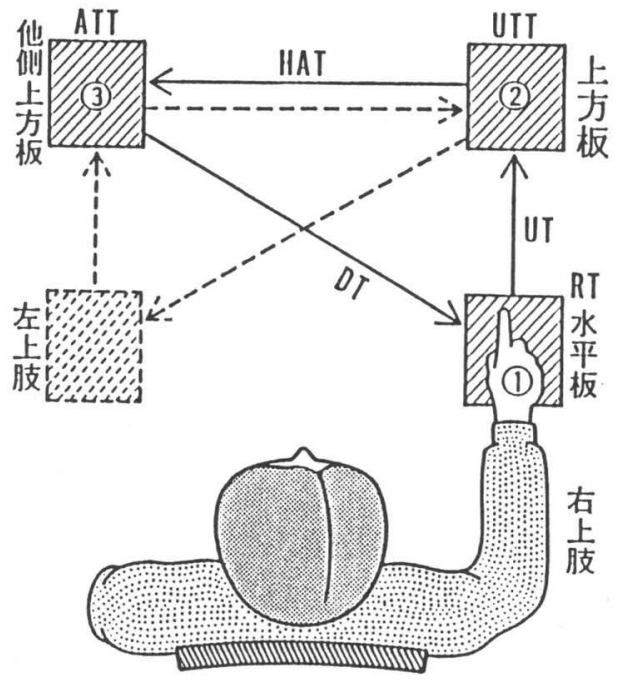

図 $1:$ 上肢 3 点上下運動

E.S

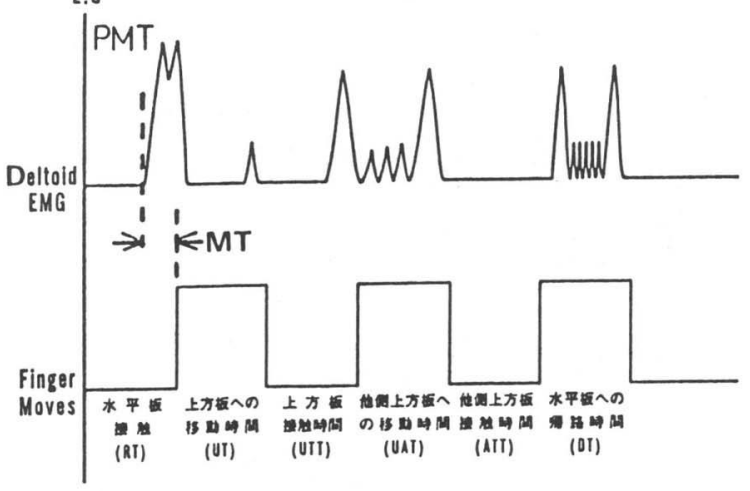

図 2:筋電図と運動軌跡 


\section{II. 方 法}

湘定方法は被験者に椅坐位をとらせ、検査 側の対側前腕屈側部に各人が自覚できる強さ の電気刺激を与え、この刺激を合図として “ 出来るだけ速く、正確に”検査側の示指を接 触板から接触板に移動運動を行わせた ${ }^{12) 。 ~}$

接触板は約 $5 \mathrm{~cm}^{2}$ の大きさであり、被験者 の前壁に検査側肩関節の高さとそれより $15^{\circ}$ 挙上位の延長上とその高さで対側肩関節部に 設置した。 3 点上下運動時には三角筋前部線 維の筋腹中央部から双極誘導法による表面筋 電図を導出し、接触板の離着動作を電位差と して捉え筋電計に同時記録した。测定は左右 上肢で各々 8 回行わせた（図 1)。

手指の離着運動軌跡に下記の名称を与えた。 電気刺激に応じて水平板から示指を離すまで を反応時間（RT）、上方板に到達するまでの 移動時間（UT）、上方板接触時間（UTT）、他
側上方板への移動時間（HAT）、他側上方板の 接触時間 (ATT)、水平板への㷌路時間 (DT) とした。なお筋電図反応時間は中村ら ${ }^{2)}$ に従 い、電気刺激から沈默期の後に出現する群化 放電までの潜時をPMT、筋活動から実際の運動 開始までの時間をMTとした（図2）。

\section{III. 結果と考察}

\section{1) 規則刺激の頻度による比較 ${ }^{132}$}

規則刺激を与えられた場合、各個体で随意 運動に参与する共同筋の筋活動のタイミング の制御を含めた上位中枢でのリズム形成化が みられる。老年者では加齢に伴って上位中枢 と効果器である筋に形態的変化、機能的低下 がみられることから、種々の刺激頻度の対応 から加齢による特徴を検索した。

対象は健常老年者 15 例（65 55 歳）と青年
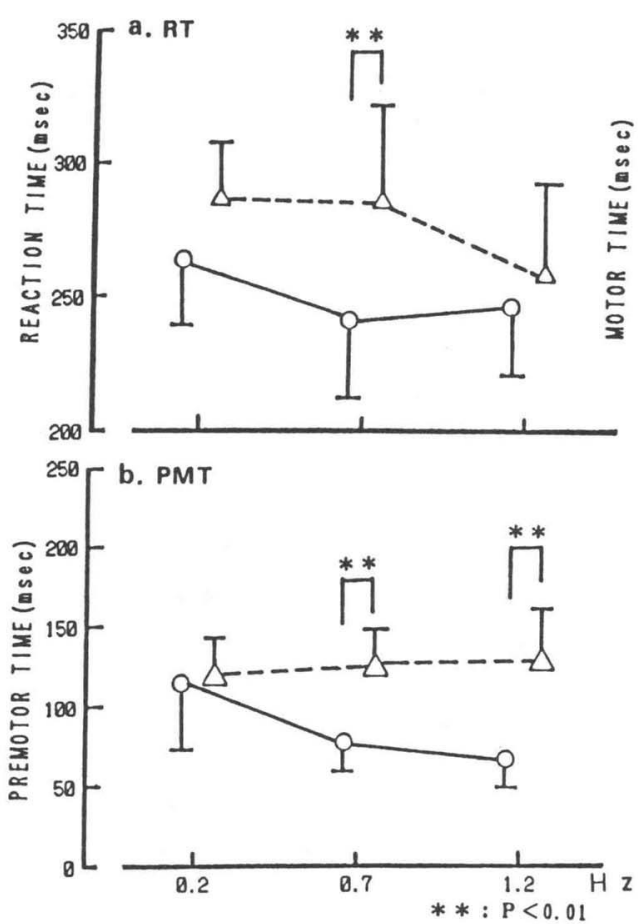

図3: 合図の頻度別による R T , P M Tおよび M T の比較

$\triangle:$ 老年群

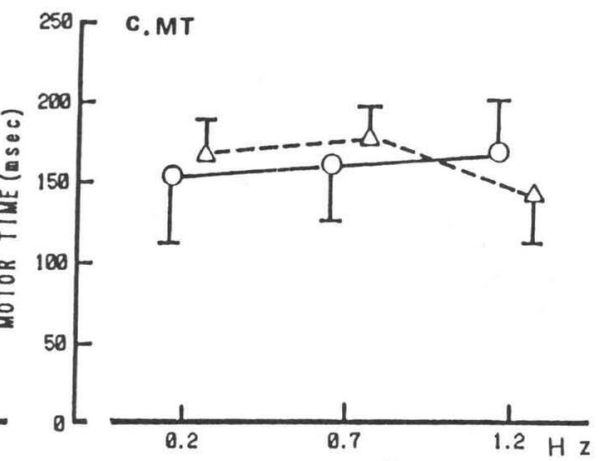

刺教頻度 


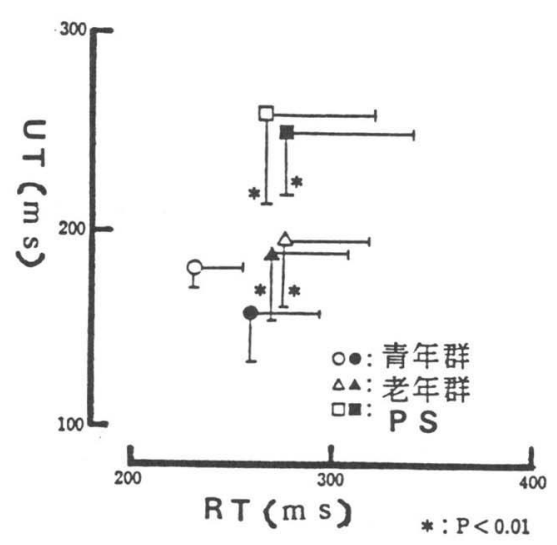

図 4: R T と U Tの関連 ${ }^{14)}$

者15例（21士1歳）であった。刺激条件として $0.2 、 0.7 、 1.2 \mathrm{~Hz}$ を用いた。

結果: RTは青年群が刺激頻度に関わらず 250 mSであったが、老年群では $0.7 \mathrm{~Hz}$ 以下が約 280 $\mathrm{ms} 、 1.2 \mathrm{~Hz}$ で約 $260 \mathrm{~ms}$ と刺激頻度の増加に伴い 約 $20 \mathrm{~ms}$ 短縮した。PMTにおける0.2 $\mathrm{Hz}$ と $1.2 \mathrm{~Hz}$ の比較では青年群が約 $33.4 \%$ の減少を老年者 では $9.1 \%$ の增加がみられた。MTにおける0.2 $\mathrm{Hz}$ と $1.2 \mathrm{~Hz}$ の比較では青年群が約 $18.0 \%$ の増 加を老年者では約 $17.3 \%$ の減少がみられた

（図 3 ）。老年者のPMTが刺激頻度の増加に伴 い延長したことから、上位中枢でのリズム形 成障害が主動筋の筋放電様式に変容を惹起し、

“運動の切り換え”に遅延をもたらしたと考 えられる。

2 ）規則刺激と不規則刺激による比較 ${ }^{10.14) ~}$

予め予期していた刺激が出現した場合には 素早く反応できるが、思わぬ刺激が現れた時 には反応が遅れる。パーキンソニズム (PS)に 対して規則刺激 $(0.2 \mathrm{~Hz})$ と不規則刺激 $(0.2$ $\mathrm{Hz}$ 末満）の電気刺激を合図に上肢の課題運動 に行わせて、運動指令の発動、刺激頻度に対 する順応能力の障害を検討した。

対象はPSが 7 例（62 13 歳）である。重症 度はYahrの分類でエ、IIIでった。対照は健

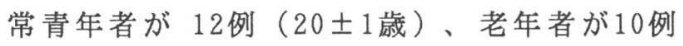
(68土5歳)であった。

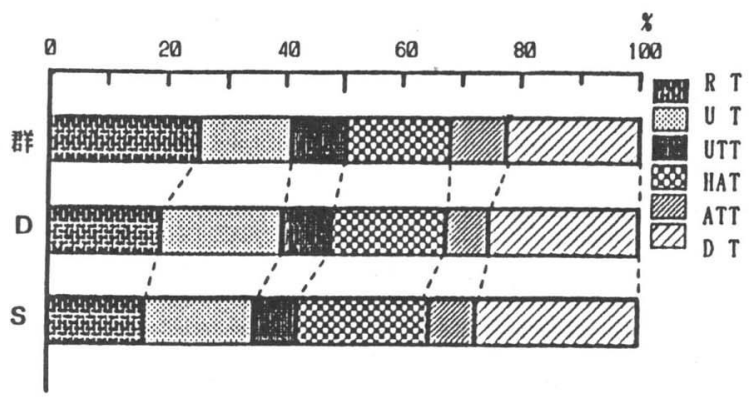

図5:不規則刺激時の全所要時間に対する 各構成時間の占める割合

結果: RTとUTの関連では老年群とPS群とも $\mathrm{RT}$ が刺激条件による差が諗められなかったが、 UTは両刺激条件で老年群よりPS群で有意な延 長がみられた（図4）。また全所要時間は 3 群とも刺激条件による差を認めなかった。全 所要時間に対するRTとUTの占める割合では刺 激条件に関わらずRTが健常群で約 $26 \%$ 、PS群 では約 $19 \%$ であった。UTでは健常群が約 $19 \%$ 、 PS群が約 $18 \%$ であった。空間移動時間の割合 は、刺激条件に関わらず青年群が約 $55 \%$ 、老 年群約 $60 \%$ 、PS群約 $66 \%$ であった。接触時間 の割合は 3 群間に差を認めなかった（図 5 ）。 PS群における遅延の要因の一つとして空間移 動時間占める割合が刺激条件に関わらず約 65 \%であったことから、筋トーヌス充進による 粘弾性の増加と筋力低下によって運動速度が 減少したものと考えられる。

\section{3) PSと小脳障害との比較 ${ }^{10,14,15)}$}

臨床症状として運動開始の遅延と運動の拙 劣を呈する春髄小脳変性症 (SCD) と PS患者 を比較することで随意運動の中枢制御機構で ある小脑と大脳基底核の役割の差異を検索し た。

対象はPSが16例（66士7歳）、SCDが12例

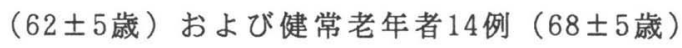
であった。課題運動は規則刺激 $(0.2 \mathrm{~Hz})$ と不規 則刺激 ( $0.2 \mathrm{~Hz}$ 未満)の合図で行わせた。

結果:PMTは老年群が刺激頻度に関わらず約 $170 \mathrm{~ms}$ と差が認められず、PS群の規則刺激で不 

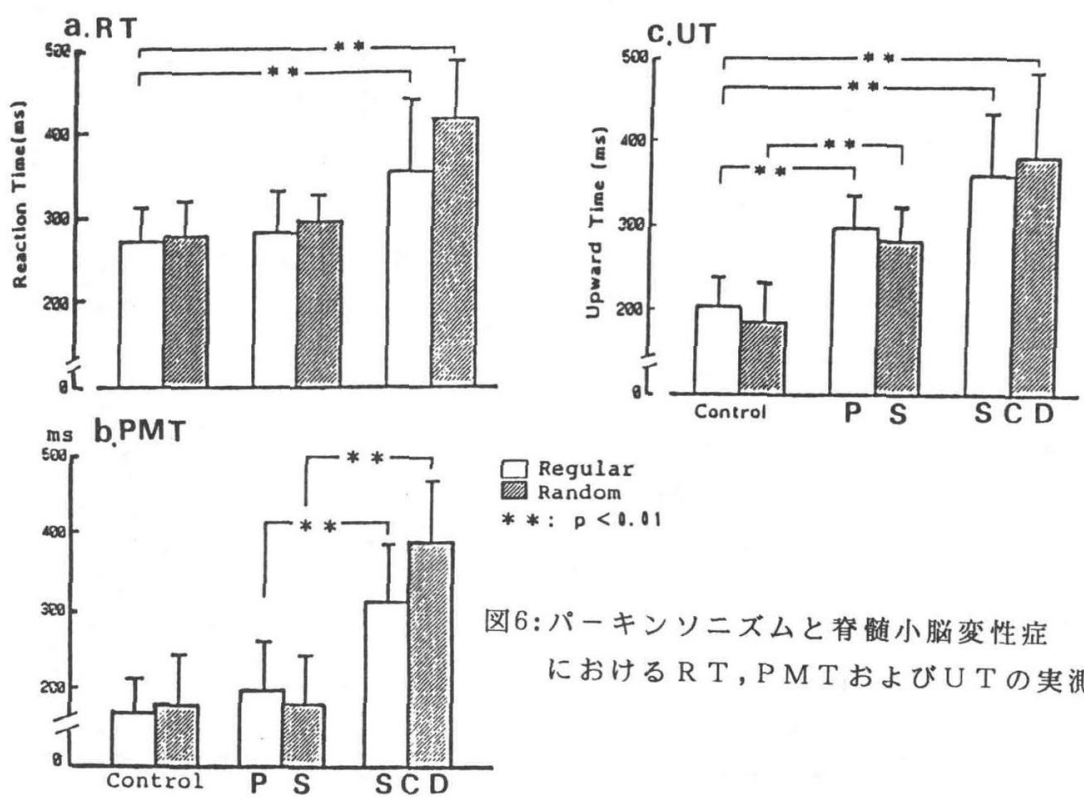

規則刺激より $23.5 \mathrm{~ms}$ 延長したが有意な差を認 めなかった（図6）。PS群ではRTのballistic な運動に遅延がみられず、UTの目想点に到達 させるための制御を必要とする運動では老年 群より有意に遅延したことから末梢効果器の 問題だけでなく、大脳基底核の機能低下によ る影響が大きいと考えられる。さらに刺激条 件における PMT、RT、全所要時間の差は殆ど なかったことから、PS群では異なる迅速運動 を要求されても、その目的にあった適切な運 動速度と瞬発力の発現が障害されているため に一定の筋腲力でしか応じれないパターン化 した運動が出現するものと考えられる。一方、 $S C D$ 群の筋放電では水平板離脱時に健常群で みられた分離性群化放電が顕著でなかった事 から、同一筋内における筋収縮の同期性障害 が推測された。また SCD群でみられた空間移 動時間の有意な延長が生じた要因には、筋緊 張及び筋力の低下と随意運動に関与する筋群 の相反性同期性収縮の障害による運動速度の 低下、企図振戦及び末梢からの種々の知覚情 報を補正するフィードバック制御機構の障害 が推測された。

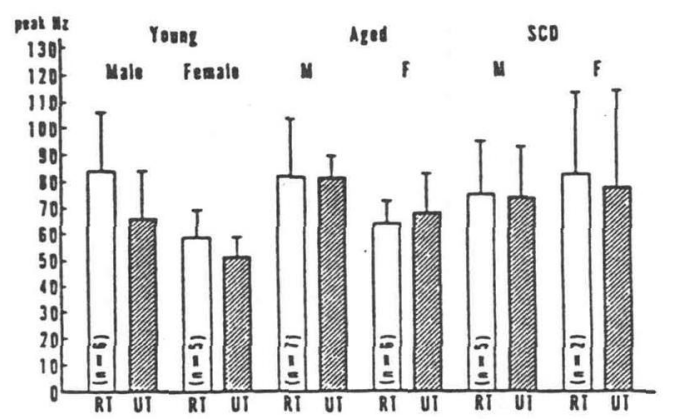

図7:RTとUTでのPeak Hzの変動 ${ }^{16)}$

4 ）接触板離着時の筋電図周波数分析 ${ }^{16}$ )

運動失調症における上肢随意運動の巧緻性 障害を運動開始時の主動筋のパワースペクト ラムの peak Hzとパターンの解析から本症で の運動中枢制御の病態を明らかにすことを目 的に行った。

対象はSCD 7 例（58 99 歳）、健常老年者 13

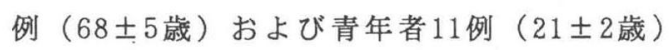
であった。課題運動は $0.2 \mathrm{~Hz}$ の規則刺激を合図 に行わせた。

結果: 肩関節屈曲 $90^{\circ}$ 保持時のpeak Hzは健 常者、SCD群ともに性差がみられ、女性が男性 より低くなる傾向がみられた。SCD群と老年群 
間に差を認めなかった。RTとUTにおける 3 群 間の比較では殆ど差を認めなかったことから、 SCD でも基本的な運動動作は維持されている と考えられる（図７）。しかし、SCD群のpeak Hzの分散は大きかった事から、中枢性運動制 御に何等かの変容が生じていることが考えら れた。

\section{5 ) 利き手の特性 ${ }^{9)}$}

EMG-RTを利用した利き手の研究は少なく、 利き手が非利き手より短縮、両者間で差を認 めないという報告があり、一致した結論がみ られないため検討した。対象は健常老年者 10

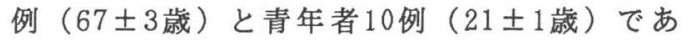
った。課題運動は $0.2 \mathrm{~Hz}$ の規則刺激で行わせた。

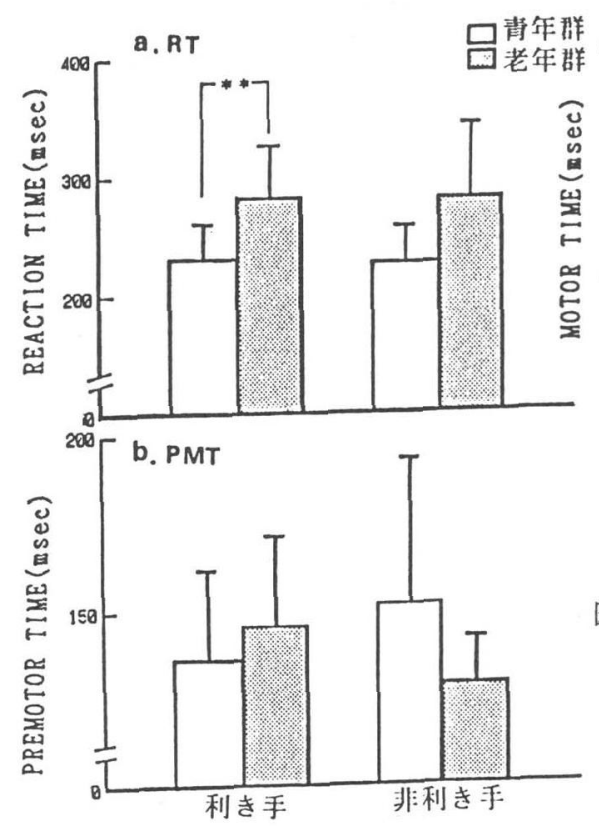

c.MT

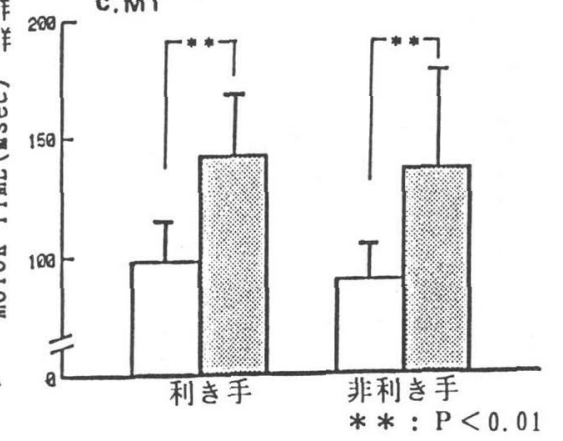

図8:利き手と非利き手における筋電図反応時 間の実測值
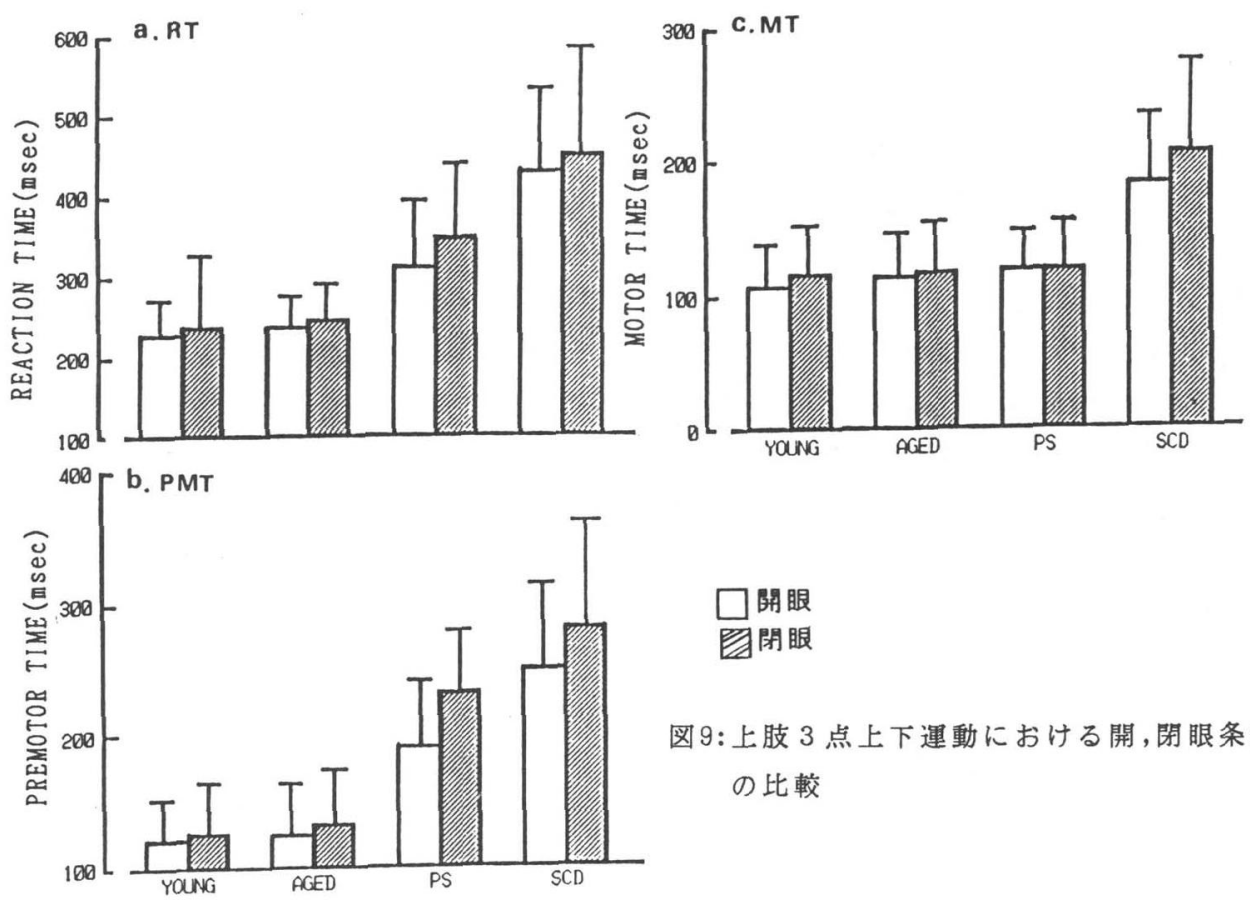

図9: 上肢 3 点上下運動における開,閉眼条件 の比較 
結果: RTは青年群が利き手、非利き手とも約 $230 \mathrm{~ms}$ 、老年群が約 $280 \mathrm{~ms}$ であり、両群とも利 き手と非利き手間に差を㒛めなかった(図 8 )。 PMTは青年群で利き手が非利き手より約 $20 \mathrm{~ms}$ 短縮したが、老年群では非利き手が約 $25 \mathrm{~ms}$ 短 縮する傾向がみられた。MTは老年群が青年群 より有意に延長し、利き手と非利き手の比較 では両群とも差を認めなかった。老年群では PMT が非利き手よりも利き手で延長する傾向 がみられたが、 $0.2 \mathrm{~Hz}$ という規則的な刺激に対 する予測の効果、課題に対する注意の集中及 び主働作筋における運動準備状態の低下によ るものと考えられる。一方、老年者にみられ たMTの延長は、加柃にともなって上肢の近位 部に筋萎縮が生じるために上肢の重みに対す る筋張力発生が低下したためと考えられる。

6 ）視覚入力の有無による筋電図反応時間 の変化

PSにおけるakinesiaの捉え方として運動命 令の伝達障害、運動学習障害、運動プログラ ミングの障害などが考えられている。本症の 運動障害では動作開始までの反応時間は不変 か軽度延與であるのに対して、運動を遂行す るために必要な筋収縮のbuild-upに遅延がみ られるという報告が多(17１8)。また本症の 運動開始障害が視覚性代償によってかなり改 善され得るため、理学療法の分野でも床梯子、 L 字杖による歩行訓練として視覚的手がかり を利用している。そこで、本症ではballistic 運動開始時にも視覚入力に依存しているかを EMG-RTから検討した。

対象は健常青年者 10 例（21士1歳）、老年者

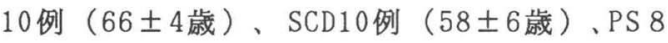
例（64 土5歳）であった。電気刺激は不規則刺 激 ( $0.2 \mathrm{~Hz}$ 末満) で与え、予め開眼で 10 回練習 した後に開眼、閉眼の 2 条件で行った。

結果: RT は健常群、SCD群で視覚情報の有無 に関わらず殆ど差がみられなかった。PS群で は閉眼が開眼より約 $32 \mathrm{~ms}$ 延長したが、梅準偏
差も大きかった。PMTは閉眼が開眼よりPS群 が約 $41 \mathrm{~ms} 、 S C D か ゙$ 約 $31 \mathrm{~ms}$ の遅延がみられた。MT は健常群、PS群とも 110-120msであったが、 SCD群が180-200ms と他の3 群より延長してい た（図 9）。PS群における閉眼時のRT延長は PMTの延長に起因していることから、視覚情報 が運動発現に大きな役割を果たしていること が推測される。またSCD群のMT延長は前述した が主動筋の筋張力発生率の低下が推測された。

\section{IV. 今後の課題}

我々は上肢における課題運動時の主動筋の 筋電図と運動軌跡の解析から随意運動を統御 する小脳と大脳基底核の機能差を検討してき た。PSでは刺激条件におけるRT、全所要時間 に殆ど差がなかったことから、運動条件が異 なっても一定の筋出力でしか応じれないパタ ーン化した運動で対応していると考えられる。 またSCDでは筋緊張及び筋力の低下と随意運 動に関与する筋群の相反性同期性収縮の障害 による運動速度の低下や末梢からの知覚情報 を補正するフィードバック制御機構の障害が 推測された。

今後は合図に対する予測効果を運動開始時 の筋電図周波数分析および運動準備状態を運 動単位の活動梯態から検索する予定である。 


$$
\text { V. 文献 }
$$

1)Weiss , A.D.: The locus of reaction time change with set, motivation and age. J.Gerontol. 20:60-64,1965.

2) 中村隆一：筋電困反応時間による運動発現 の検討,臨床脳波 $30: 566-572,1988$.

3) 大山正: 反応時間研究の歴史と現状, 人間工 学 $21: 57-64,1985$.

4) 佐直信彦 - 他：他動運動の反応時間への影 響,臨床脳波 $31: 285-288,1989$ 。

5) Evarts E. V., et al. :Reaction time in Parkinson's disease. Brain 104:167-186, 1981.

6) Yokochi F., et al.:Reaction time of patients with Parkinson's disease, withreference to asymmetry of neurological signs. J. Neur. Neuros. Psych. 48:702-705, 1985 .

7) 横地房子. 他 : 基底核と精神運動機能一パ 一キンソン病患者における反応時間研究を とおしてー, 神経進歩 30:841-846, 1986.

8) 洞口充: 手背屈動作反応時間に対する同時 足背屈動作の影響，リハ医学 $21 ： 95-99$, 1984.

9)岩月宏泰・他：加踚による手の反応時間の 変化, 運動生理 $5: 65-70,1990$.

10) Iwatsuki,H. \& Muroga,T. : Analysis of component times in the stereotyped movements of upper extremities by regular and random signals. J.Phys. Ther.Sci. ,3:13-18,1991.

11)Tsuji I., et al.: The altered time course of tension development during the initiation of fast movement in hemiplegic patients. Tohoku J. exp. Med. 151:137-143,1987.

12 ) 室賀辰夫 ・ 他 : 上肢三点上下随意運動過程 での左右差, 厚生省特定疾患・運動失調症調 査研究班, 昭和61年度研究報告 p. 80-86.

13) 岩月宏泰 - 他 : 上肢随意運動における刺激 頻度と時間的コンポーネントの関係, 運動生 理 $2: 67-70,1987$.

14)岩月宏泰・他：パーキンソニズムにおける 接触板移動運動の時間的解析, 理学療法学 16 : 297-302,1989.

15)岩月宏泰 - 他：上肢随意運動遂行過程の解 析一小脳障害者と健常者の比較一, 理学療法 学 $15: 409-414,1988$.

16) 室賀辰夫 ・ 他 : 上下と 3 点の上肢運動時 の筋放電の周波数解析, 厚生省特定疾患 . 運動失調症研究班, 昭和 63 年度研究報告 p. 104-108.

17) Evarts E. V., et al. :Behavioral correlates of activity in basal ganglia neurons. Trends in Neurosci 7:447-453, 1984.

18) 中野知幸 ・他：パーキンソニズムの奖勢保 持障害について, 臨床神経 20:924,932, 1984 . 